\title{
VIRTUAL COMMUNITIES FOR SMES: A CAUTIONARY TALE OF AN ELECTRONIC MARKETPLACE
}

\author{
Janice M. Burn \\ School of MIS, Edith Cowan University, Joondalup Campus, Perth. WA.
}

\begin{abstract}
This paper reviews the concepts of virtual communities and electronic marketplaces and, in particular, their relevance for SMEs. A specific example of a Regional Electronic Marketplace (REM) using a Community Web model is examined within this context. The author reviews the underlying philosophy for the project and the planning which preceded implementation. A review of the case highlights the issues which are critical for successful implementation and provides a framework to guide future REM developments. The case is analysed within an e-community context and recommendations made for future portal developments. Finally the author questions the readiness of SMEs to adopt a virtual organisation model.
\end{abstract}

Key words: virtual communities, small and medium enterprises (SMEs), electronic marketplaces

\section{INTRODUCTION}

International reports show an increasing uptake of online activity in the Small to Medium Enterprise (SME) sector, but, there is little evidence to link this with real added value or increased levels of global business (Fariselli et al, 1999, Tetteh and Burn, 2001). Research indicates that SMEs are still confused by the myriad opportunities presented by different e-markets, the risks inherent in going online and the need for different business models with strategic national and international alliances to exploit the global marketplace (Kleindl, 2000). By nature SMEs are typically lone rangers and ill prepared 
for virtual organisations where the focus is on alliances and networking with collaborators and competitors (Carver, 1999; Lee et al, 2003).

SMEs represent a vast sector of the global economy (OECD, 2000). In Australia they account for $95 \%$ of companies and are the largest employer of labour in both urban and regional Australia [www.noie.gov.au]. Their combined turnover contributes substantially to the economic vitality and dynamism of the Australian economy. This is not unique to Australia but is mirrored in most economies around the world. As such there has been considerable interest in the take-up of e-business by SMEs allowing them to expand into a global marketplace. Internet-based electronic business is projected to rise from the current estimated level of US $\$ 2$ trillion in world-wide revenue to between US\$ 5-9 trillion by 2005 (UNCTAD, 2002). Attention is being focused on SMEs as additional sources of national and global competitiveness, market innovation and job creation. Recent research indicates however that Australian SMEs are hesitant in their approach to e-business (SBI, 2001; DCITA, 2000) and lag behind many other developed economies in exploiting the Internet. An OECD report "Enhancing the Competitiveness of SMEs in the Global Economy: Strategies and Policies" (2000) found that the penetration rate of the Internet for e-business in the Australian SME sector was only $25 \%$ compared with figures of over $60 \%$ in Europe for example. The Pacific Access Survey (2001) shows a slight increase with $31 \%$ of small businesses with a home page or dedicated Internet site and $26 \%$ using the web for procurement out of a sample of 1800 Australian SMEs.

In Australia, as in other developed countries, research studies have focused on the adoption and use of the Internet as a medium for doing business by SMEs (Poon and Swatman, 1997; Swatman, 2000; OECD, 1998; Bode and Burn, 2001). These studies point to some of the common characteristics of SMEs with respect to adoption levels, challenges, and general benefits from online infrastructures. While there appears to be much enthusiasm about electronic business, current studies show that it is the minority of SMEs who are reaping significant benefits from the Internet (Burn and Tetteh, 2001; Bode and Burn, 2001a; Levy and Powell, 2003). The majority of SMEs use the Internet only as a basic communications facility (Burn and Spadacinni, 1999). The reasons for the relatively low level of use include: the lack of technological expertise, uncertainty about benefits, low commitment of owner/manger, poor understanding of the dynamics of the electronic marketplace and their inability to devise strategies to leverage online infrastructure for profit (Standing 2001). Indeed, the ability to use IT in an effective manner is still of major concern to policymakers worldwide in respect to leveraging SMEs' productivity and global participation ( Fariselli et al, 1999; Grewal et al, 2001). One of the solutions which is suggested for more effective IT penetration is the use of third party providers of IT services and 
the development of electronic markets specifically for SMEs (Kaplan and Sawhney, 2000; Grewal et al, 2001). This paper reports on one such development and evaluates the success within a virtual community context.

\section{E-MARKETPLACES}

The emergence of electronic marketplaces creating trading hubs where suppliers are matched with buyers for equipment, products and services has the potential to a play a major role in realising the potential of e-commerce for SMEs. Indeed, if SMEs are to remain competitive they need to adopt the changes that are occurring in the area of electronic commerce (Standing and Vasudavan, 1999; Bode and Burn, 2001b).

An electronic marketplace is defined as an 'inter-organisational information system that allows the participating buyers and sellers to exchange information about prices and product offerings' (Bakos, 1991, p 296). The profusion of these electronic marketplaces, the speed of transition to the electronic environment, the variety of business models and the varying requirements of different industries and service sectors cloud an already confused marketplace picture (Grewal et al, 2001). Despite this, there is immense pressure on companies to move quickly to the electronic marketplace, often without a full understanding of what benefits they can accrue from participation in them and the issues that should be considered in the selection process (Banham, 2000). It is clear that this type of e-trading is threatening the more fixed forms of virtual supply chains where an organisation is integrated electronically with its suppliers down the supply chain (Clark and Lee, 1999).

Previous studies have identified the different levels of service that are offered by e-marketplaces, developing from trading hubs that support the identification of potential trading partners to more complex models offering selection and, increasingly, execution services (Choudhury, Hartzel and Konsynski, 1998). The models that have developed offer the following methods of trading:

- Catalogues

- Auctions

- Exchange

- Storefronts either individual vendor or multi-vendor buyer or seller driven

comparable to trading exchanges with a bid and ask system

participants maintain an open Webpage within the marketplace

- Negotiation the marketplace acts as intermediary for transactions such as RFQs

The reported benefits to companies that are trading through emarketplaces are compelling and suggest that cost savings being experienced 
by companies are considerable. Lucking-Reiley and Spulber (2000) estimate that online transactions could reduce costs by a factor of five or ten or more. Typical cost saving efficiencies are lower procurement and search costs, reduced administration costs and development time, integrated global suppliers and a strengthening of relationships with commercial partners, cuts in inventory holdings and up-to-the-minute order tracking. Non-financial benefits include access to better quality goods and services, value adding information obtained from the e-marketplace, greater choice in the buying/selling process and greater convenience for participants (Standing 2001).

The scope of the individual marketplace will determine how many of the benefits can be experienced by the participants of a particular marketplace. One of the major issues for SMEs is whether to select a "horizontal" or "vertical" portal as the market model. Horizontal markets offer an open shopping mall experience with a wide variety of goods, whereas vertical portals cluster together similar industries and will attract product specific shoppers. An SME has to make the decision as to whether they gain competitive advantage from a unique product in an open marketplace or to ally with competitors to offer a wider range of products in a discrete marketplace. The element of choice in selecting an e-marketplace is often constrained by traditional partners or the positioning of major industry players.

Our ongoing research indicates that even where SMEs have some awareness and use of e-commerce there still remain problems (Tetteh and Burn, 2001, Bode and Burn, 2001a). For example, the expectations of a positive impact from the Web are unlikely to be fully realised as only approximately one third of Web enabled SMEs have any form of a Web strategy. SME websites are primarily information sites for customers and only $20 \%$ are capable of taking an order online (Korchak andRodman, 2001). Less than a third of SMEs use the Web for procurement and there has been low penetration of e-marketplaces Although e-marketplaces are being increasingly used by large organisations, which have been quick to realise their potential, SMEs have been slow to take up their adoption as a mechanism for buying and selling.

Many of the problems relating to the failure of SMEs to address the importance of electronic marketplaces lies in a lack of understanding of the advantages and how they can benefit from them. SME understanding of the global marketplace is not good and they have little idea of the nature of the Internet and how it interacts with other methods of trading. Smaller companies do not see themselves as part of a large supply chain and they underestimate how the Web can benefit them by sharing information, buying from suppliers with no paper system, electronic fulfilment, tracking, and efficiencies in cost and time (Korchak and Rodman, 2001). If they do not understand their ability to function within the larger supply chain they will lose 
out to large firms in the electronic markets. The developing world markets, brought about by e-commerce and the increased ability to trade globally facilitated by electronic markets, adds to pressure on the SMEs as there are more firms with the ability to trade in each region (Said, 2000).

Increasing globalisation and a climate of more outsourcing has both increased the pressures on SMEs to perform, but also extended the opportunities for them to do so. SMEs have little control over the market so must harness the pressure and respond quickly (McAdam, 2000) utilizing the advantages of electronic markets. The main influences on e-commerce adoption are size, leadership/culture, IT experience and access to skills (Jones et al, 2000). An added complication comes from poor understanding of the participation requirements in electronic marketplaces and the motivation and activity levels necessary to achieve meaningful benefits (Kleindl, 2000; Grewal et al, 2001).SMEs require assistance to acquire the necessary skills and knowledge to make the move to the electronic environment and evidence suggests that this help needs to come from neutral sources such as government or business associations (Burn and Tetteh, 2001; Fariselli et al, 1999). As a result we are increasingly witnessing the emergence of virtual communities sustained by regional portals (Cowan et al, 1998: Burn and Zanaboni, 2003).

One such example of Government supported marketplace development can be found in the 2Cities.com regional electronic market developed for the regions of Joondalup and Wanneroo in Western Australia. The 2Cities project offers SMEs an opportunity to select their preferred business model and to develop their strategy for online business in accordance with their preferred business philosophy. This unique concept combines both horizontal and vertical marketplaces and provides the underlying business infrastructure for SMEs to take advantage of electronic trading.

\section{PLANNING FOR THE REM}

As early as 1999, a small group of interested parties came together to discuss whether the Internet could be used to facilitate a community portal for a regional community area north of Perth in Western Australia. The region was Joondalup, a rapidly developing suburban 'new town' area and the players were the local council, the Business Enterprise Centre and the local Business Association. These key players realised that funding support would be needed but also that they could substantially increase their bargaining power by extending the concept to their neighbouring region - Wanneroo (despite a highly competitive and sometimes acrimonious relationship). This enhanced stakeholders group included both councils and business associa- 
tions and also the University with the largest campus in the area, Edith Cowan University and two local colleges in the same education precinct. The stakeholders were approximately 220,000 residents, 7000 small businesses and three Tertiary Education Facilities. This group together sought seed funding of $\$ 20,000$ from State Government and in 2000 developed a demonstration site to sell the concept.

A survey of 1000 of these businesses conducted in association with Edith Cowan University comprising 600 businesses in Joondalup and 400 businesses in Wanneroo indicated that e-commerce usage in 2001 was fairly high as shown in Table 1.

\begin{tabular}{|l|c|c|c|c|}
\hline \multicolumn{2}{|c}{ Joondalup } & Wanneroo & $\begin{array}{c}\text { Australian } \\
\text { Average }\end{array}$ \\
\hline \hline & & & Small & Medium \\
\hline & $\%$ & $\%$ & $\%$ & $\%$ \\
\hline Internet Connection & 58 & 60 & 60 & 89 \\
\hline Web Page & 44 & 40 & 25 & 56 \\
\hline Purchase on Line & 31 & 27 & 17 & 28 \\
\hline Sell on Line & 31 & N/A & & \\
\hline Business needs Web Page & 23 & 20 & & \\
\hline
\end{tabular}

Table 1. e-Commerce Usage in 2Cities area

This indicated that businesses in the region were at least as well advanced as average Australian businesses, and possibly more advanced in the areas of web page and on-line transactions. The REM project was given the go-ahead by NMCOA in conjunction with business for the benefit of businesses in the region and to develop the Northern Suburbs as an attractive location in which new business can develop and grow. The initiative intended to train businesses in the skills required to buy and sell on-line and also allow easy access to the products offered by these businesses to the major consumers in the region.

Specifications were developed and budgets proposed and when the extent of funding and commitment required was fully understood the North Metro Community On-Line Association (NMCOA) was formed in March 2001. Additional funding was sought from the Department of Employment, Workplace Relations and Small Business (DEWRSB) under the Regional Assistance program (RAP) and a grant of $\$ 90,660$ received. At this time, the three main players, the two councils and the university were asked to make a substantial investment in the concept and provided funding of $\$ 108,000$. NMCOA would act as an independent body to manage finances and control the development of the REM. 
Discussions by NMCOA's Business Development Manager (PM-A) with a wide range of businesses indicated the clear expectation that the project would assist them to accelerate entry to the on-line market place, provide them with a wider market in the regional context and allow them to use these technologies to become globally competitive.

Other factors that the businesses would be looking for in the REM included: -

- High profile.

- Secure business transactions.

- Information feedback on visits to the site.

- Support to allow them to effectively enhance web sites with reasonable cost effectiveness.

- An independant source of technical expertise and advice they could trust.

The 2Cities Gateway Project would provide, through a "Community Web" model, an official portal to be a single point of entry for individuals, communities, governments (Federal, State and Local), and business to access and interact within the Wanneroo/Joondalup region. The gateway would also provide the basis for regional online information exchange activities and encourage, support and develop awareness of the benefits and use of the Internet technology. 2Cities is about re-establishing a village community in a networked world:

'Our goal is "e-inclusion" - by having Residents, Community Groups and Businesses interacting online. Importantly, it's not just about technology rather we're developing a tool for all groups within our community to interact with each other. It will also build our region as a "Smart Region" to put us at the forefront of the information economy and reap the benefits of cost saving from effective use of the Internet'.

As a regional access point there would be a broad focus, providing a single 'official' point of entry for a range of community, business and other services and products of the region. Additionally, educational services, business products and services, institutions and services, business to business transactions, community groups needs, associations, and marketing of the region for social, economic and other development would be provided.

\section{PROJECT DEVELOPMENT}

The objective of the project was to develop an e-marketplace within the community (Figure 1). This would be known as the Regional Electronic Marketplace (REM). 


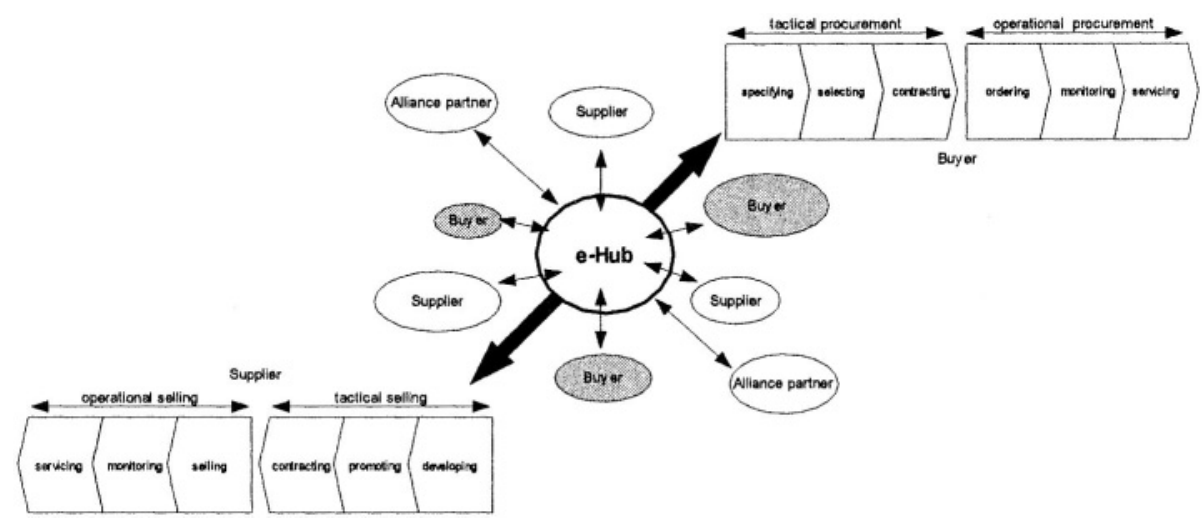

The e-Marketplace is meant to permit Joondalup and Wanneroo region based businesses to sell, but theoretically anyone worldwide to buy through the e-Marketplace once registered. This policy is intended to give to business settled inside this region an infrastructure that can be a competitive advantage, and could also encourage relocation of business. In addition, 2Cities is meant to develop the communities of Joondalup and Wanneroo and to offer a marketing service for promoting the area, through directories like: environment, sport, tourism and education. Finally there's the plan to try to foster local job recruitment, as another way to improve the attractiveness of the region.

The 2Cities supports five different types of e-business relations:

- Business to Government (B2G): supporting all the procurement activities (tenders and normal purchases) of government structure (Administration, Education and Health) both inside and outside the region.

- Government to Consumer (B2C): letting people both inside and outside the region obtain information from the different government structures inside the region.

- Business to Business (B2B): letting business both inside and outside the region once registered to buy from registered businesses inside the region.

- Business to Consumer (B2C): 2Cities will be used by consumers both inside and outside the region basically to search for a business inside the region, but the system also supports the full range of $\mathrm{B} 2 \mathrm{C}$ eCommerce.

- Consumer to Consumer (groups) (C2C): developing an active online community for social groups and social services

Organisations seeking to purchase goods or services can use the model to send RFQs, lodge orders and segregate suppliers by locality. Sellers can be notified of RFQs by e-mail, fax or SMS and orders can be placed in a similar manner. In order to sustain the market large corporate buyers have to commit to the market and support agreed from the cities of Joondalup and Wan- 
neroo, Mindarie Regional Council and the university. This will also supply buyers with easy access to a large range of suppliers and choice of goods, and increase their ability to obtain competitive pricing. In addition it is anticipated that suppliers operating within the marketplace will use the process to purchase their own requirements, and in so doing increase the level of trade within the region. Expansion of the system to allow the regions domestic consumers to purchase on-line has the potential to result in rapid growth in transaction levels. Once familiar with e-trading and having benefited from increased regional sales, business will be in a position to expand outside the region, to state, interstate and overseas markets.

NMCOA and the Business Associations believed themselves well placed to assist companies in this type of expansion and where required arrange introductions to local companies already operating in these marketplaces. Such a mentoring process can lead to efficient entry into new markets. Training is an additional requirement and the Small Business Development Corporation provided $92,000 \mathrm{~A} \$$ to recruit a training officer for the REM. The 'conservative' estimate used in the business model was that some 1,200 companies would be operating within the e-marketplace within five years.

\section{PROBLEMS IN THE DEVELOPMENT}

Table 2 shows the development timetable, some of the key players and the major milestones impacting on implementation of the portal. The problems can be summarised as follows:

- poor business plan

- low capitalisation

- project overrun

- poor project management - 3 separate project managers

- mis-timing of training requirements

- no marketing and training budgets

- 'warring' stakeholders

- limited understanding of stakeholder needs and motivation

\begin{tabular}{|l|l|l|l|l|}
\hline Year & Stage & $\begin{array}{l}\text { Project } \\
\text { Manager }\end{array}$ & Situation & Income \\
\hline 1999 & $\begin{array}{l}\text { Joondalup } \\
\text { Stakeholders } \\
\text { Group }\end{array}$ & PM-A & Small group gathering & N/A \\
\hline 2000 & Wanneroo/ & PM-A & Creating the basic group of & 20.000 A from the \\
\hline
\end{tabular}




\begin{tabular}{|c|c|c|c|c|}
\hline & $\begin{array}{l}\text { Joondalup } \\
\text { Regional } \\
\text { Online Steer- } \\
\text { ing Commit- } \\
\text { tee +ECU }\end{array}$ & & $\begin{array}{l}\text { stakeholders, the "demonstration } \\
\text { site" is put online by Joondalup } \\
\text { Business Association }\end{array}$ & State Government \\
\hline $\begin{array}{l}\text { Mar } \\
2001\end{array}$ & NMCOA & PM-A & $\begin{array}{l}\text { The NMCOA is created to be a } \\
\text { separate financial and political } \\
\text { body from stakeholders that can } \\
\text { receive and manage founds }\end{array}$ & $\begin{array}{l}90,660 \text { AS } \\
\text { from Federal Gov- } \\
\text { ernment (RAP) } \\
108.000 \text { AS from the } \\
2 \text { cities and ECU }\end{array}$ \\
\hline $\begin{array}{l}\text { Feb } \\
2002\end{array}$ & $\begin{array}{l}\text { IBC win con- } \\
\text { tract }\end{array}$ & $\begin{array}{l}\text { PM-A } \\
\text { becomes } \\
\text { PT con- } \\
\text { sultant }\end{array}$ & Development of Portal & $\begin{array}{l}70.000 \text { AS for con- } \\
\text { tract }\end{array}$ \\
\hline $\begin{array}{l}\text { May } \\
2002\end{array}$ & & PM-B & $\begin{array}{l}\text { PM-A resigns } \\
\text { PM-B appointed } \\
\text { TM appointed }\end{array}$ & $\begin{array}{l}92,000 \text { AS SBDC } \\
\text { grant for TM }\end{array}$ \\
\hline $\begin{array}{l}\text { Aug } \\
2002\end{array}$ & $\begin{array}{l}\text { Portal in test } \\
\text { phase }\end{array}$ & PM-C & $\begin{array}{l}\text { PM-B appointment withdrawn } \\
\text { PM-C appointed } \\
\text { TM resigns }\end{array}$ & \\
\hline $\begin{array}{l}\text { Dec } \\
2002\end{array}$ & $\begin{array}{l}\text { Portal com- } \\
\text { pleted (6 } \\
\text { months over- } \\
\text { due) } \\
60 \text { users }\end{array}$ & PM-C & Soft launch of 2 Cities.com & A\$190 each \\
\hline $\begin{array}{l}\text { Feb } \\
2003\end{array}$ & $\begin{array}{l}\text { Intended } \\
\text { launch }\end{array}$ & PM-C & $\begin{array}{l}\text { Delayed - new business plan } \\
\text { developed }\end{array}$ & $\begin{array}{l}\$ 50,000 \text { additional } \\
\text { revenue sought from } \\
2 \text { councils }\end{array}$ \\
\hline $\begin{array}{l}\text { June } \\
2003\end{array}$ & Crisis Meeting & PM-C & $\begin{array}{l}\text { Threat of bankruptcy - stalemate } \\
\text { between councils and Business } \\
\text { associations - Revised business } \\
\text { plan developed - PM-C re- } \\
\text { trenched }\end{array}$ & \\
\hline $\begin{array}{l}\text { Oct } \\
2003\end{array}$ & $\begin{array}{l}\text { Marketing } \\
\text { manager ap- } \\
\text { pointed }\end{array}$ & $\mathrm{MM}$ & $\begin{array}{l}\text { Network found to be unusable - } \\
\text { IBC take portal in-house }\end{array}$ & \\
\hline
\end{tabular}

\begin{tabular}{|l|l|l|l|l|}
\hline Year & Stage & $\begin{array}{l}\text { Project } \\
\text { Manager }\end{array}$ & Situation & Income \\
\hline $\begin{array}{l}\text { Dec } \\
2003\end{array}$ & $\begin{array}{l}\text { MM reports 3 } \\
\text { new users }\end{array}$ & MM & $\begin{array}{l}\text { 2Cities put into abeyance until } \\
\text { February 2004 }\end{array}$ & $\begin{array}{l}\text { Realistic accounts } \\
\text { show balance of } \\
\$ 1000\end{array}$ \\
\hline March & Appointment & MM & New Sales plan to be supported & Sales average 10 per \\
\hline
\end{tabular}




\begin{tabular}{|l|l|l|l|l|}
\hline 2004 & $\begin{array}{l}\text { of 2 Tele- } \\
\text { marketers } \\
\text { RFQ for re- } \\
\text { view of IBC } \\
\text { services }\end{array}$ & $\begin{array}{l}\text { by PT TMs } \\
\text { External consultant submits } \\
\$ 11,000 \text { proposal for evaluation }\end{array}$ & week \\
\hline $\begin{array}{l}\text { April } \\
2004\end{array}$ & MM resigns & & $\begin{array}{l}\text { Sales averaging 2 per week led } \\
\text { to decision to offer MM com- } \\
\text { mission only position }\end{array}$ & $\begin{array}{l}\text { Board meeting } \\
\text { called for dissolu- } \\
\text { tion of REM }\end{array}$ \\
\hline
\end{tabular}

Table 2.Project Development Stages

The initial business plan was almost wholly dependent on grant income which did not materialise and with unrealistic costs for REM users $(\$ 500$ per annum as compared to a final fee of \$199). The founding members did not realise the extent to which additional funding would be required nor the full extent of technical expertise which would be required to implement the portal. Project managers came and went (three over one year) and a training manager was appointed over six months before the implementation of the portal and resigned prior to the test period. The 2 Cities budget had no provision for marketing or training costs and while the revised business plan now includes provision for marketing there is a completely unrealistic target of 6 new users per day signed by the marketing manager. Additional funds (through government grants or through voluntary contributions from the partners) must be obtained.

\section{ISSUES AND LESSONS FOR FUTURE}

The current status of 2Cities.com is that it commenced operation in December 2002 although the 'official' launch has not taken place and various 'take-over' bids are under discussion. To-date 159 businesses and 39 community groups are registered in the portal. However, less than half of these (78) are actually paying customers and there is no record of any successful trading activity.

Williams and Cothrel (2000) define an online community as groups of people engaging in many-to-many interactions and the motivation for the engagement is the shared interest in certain products. The idea behind such business-related communities is to adapt businesses to the culture of the internet by providing consumers with the ability to interact with each other in addition to the company (Armstrong and Hagel III, 1996). It is not required that members of such communities share beliefs or a feeling of belonging together, However Williams and Cothrel identify three activities which are central to the success of every online community: member devel- 
opment, asset management and community relations and these are examined in turn with respect to problems which have arisen within 2Cities.com.

\subsection{Member Development}

Communities need critical mass to remain active.The 2Cities business model adopted is one which is totally dependent on a critical mass of large corporate buyers. The portal, however, does not necessarily offer any advantages to these groups since the sellers, typically SMEs, are unlikely to be able to offer discounted prices for large orders. Promotion is essential to build the community but, in fact, 2Cities.com has no marketing budget.

\subsubsection{Asset Management}

Assets in an online community range from content; to alliances with other groups; to the knowledge and experience of experts, to the community infrastructure. The community coordinator needs to capture the information members need but 2Cities has two customer communities as a focus, the REM community and the social community. These two groups have very different needs from an online community, require different support and need different training. Content generation is required for each of the five types of e-commerce supported in the portal, each involving very different players but all required to adopt some basic standards. An on-going Project Manager is essential.

\subsubsection{Community Relations}

Interaction with other people is essential for successful creation of an active online community but requires online moderation and facilitation. The desired 'village community' of 2Cities.com will require constant moderation yet has to stimulate member generated content which will be seen to be of value to a very diverse community. There is an additional political dimension here since the two communities are in fact, quite competitive and do not normally view themselves as a single group.

Armstrong and Hagel III (1996) distinguish four types of community as communities of transaction, communities of interest, communities of fantasy and communities of relationship and argue that these are not mutually exclusive and further that communities would miss out on business opportunities if they do not cover all of them. However, managing the complexities of these relationships presents a real challenge to SMEs and the business groups associated with them and seems to be at the heart of the problems 
involved in 2Cities development. One solution may be to consider the community holistically as a virtual community.

\section{VIRTUAL COMMUNITIES}

Lee et al (2003), propose five stages of growth for a virtual community as:

1. Fundamental understanding of concepts, principals, definitions and models

2. Technology development for sustained growth

3. Protocols for applications development, relationship building and knowledge sharing

4. Evaluation of implementation and outcome assessments

5. Institutionalisation and enlargement of benefits.

These stages may well be appropriate for an integrated and IT active community with high levels of motivation to interact (Grewal et al, 2001) but need to be preceded by additional steps when small businesses are involved and the 'village' concept embraced. These include:

1. Developing real understanding of benefits from e-communities

2. Stimulating and nurturing motivation to actively participate

3. Education and training on IT and e-business for all users

4. Gaining commitment from all stakeholders

5. Realistic budgeting and hands on project management

As with many such IT ventures it is not just securing the technology but also developing the social interfaces and commitment to participate which will lead to virtual community development.

\section{CONCLUSIONS}

This paper describes an approach to developing an online regional marketplace associated with a community portal. While there is no dispute that real value can be obtained from online communities (Lueg, 2003) the factors which contribute to the success of such communities seem to be little understood by small players in the market. The case of 2Cities.com illustrates some of the problems and highlights the need for far more effective social management of all the implementation issues. The approach suggested here requires the adoption of a holistic virtual community model which can develop through a series of well defined and more importantly well managed stages. 
There is a real need to develop e-markets to allow SMEs to capitalise on online trading but the marketplace must acquire a critical mass of players and must also offer a real alternative to large corporate buyers. 2Cities.com is an extremely ambitious project which is still in its infancy. The revised business plan includes provision for three new REM participants captured every half day over the next year. Time (and a very depleted budget) will prove whether this is a realistic proposition.

\section{REFERENCES}

Armstrong A. and Hagel III, J. (1996). The Real Value of On-Line Communities. Harvard Business Review, May-June, 134-141.

Bakos, J. Y. (1991). A strategic analysis of electronic marketplaces. MIS Quarterly, Vol. 15, 3, 295-310.

Banham, R. (2000). The B-to-B virtual bazaar. Journal of Accountancy, Vol 190(1), pp 2630.

Bode, S. and Burn, J. M. (200la). Website Design Consultants, Australian SMEs and Electronic Commerce Success Factors. International Journal of Business Studies, Vol, 9, No 1, 73-85.

Bode, S. and Burn, J. M. (2001b). Strategies for Consultancy Engagement for e-Business Development - a case analysis of Australian SMEs. In Burgess, S. (Ed). Managing Information Technology in Small Businesses: Challenges and Solutions. Idea Group Publishing.

Burn, J. M. and Spadaccini, A. (1999). On-Line Organisations - the hype,myths and realities. A Study of IT enabled communication in organisations in WA ACIS Conference, Wellington, New Zealand, Dec.

Burn, J. M. and Tetteh, E. (2001). A Framework for the Management of Global e-business in Small and Medium Sized Enterprises. In P. Palvia, P. Palvia and E.Roche (Eds), Global Information Technology and Electronic Commerce- issues for the new millenium, Ivy League Publishing.

Burn J. M, and Zanaboni, C. (2003) A Tale of 2Cities.com. PACIS, Adelaide, July

Carver, C. (1999). Building a Virtual Community for a Tele-Learning Environment. IEEE Communications. Vol. 37, 3, 114-118.

Choudhury, V., Hartzel, K. S., and Konsynski, B. R. (1998). Uses and Consequences of Electronic Markets: An Empirical Investigation in the Aircraft Parts Industry. MIS Quarterly, Vol. 22, 4, 471-507.

Clark, T.H., and Lee, H. G. (1999). Electronic Intermediaries: Trust Building and market Differentiation. Proceedings of the Thirty-second Annual Conference on System Sciences.

Cowan, D., Mayfield, C., Tompa, F. and Gasparini, W. (1998). New Roles for Community Networks. Communications of the ACM, Vol. 41, 4, 61-63.

DCITA (Department of Communications, Information Technology and the Arts). (2000). ECommerce Beyond 2000. Commonwealth of Australia, Canberra.

Fariselli, P, Oughton, C., Picory, C. and Sugden, R. (1999). Electronic Commerce and the Future for SMEs in a global Market-Place: Networking and Public Policies. Small Business Economics, Vol. 12, 3, 261-176. 
Grewal, R., Comer, J. M. and Mehta, R. (2001). An Investigation into the Antecedents of Organizational Participation in Business-to-Business Electronic Markets. Journal of Marketing, Vol. 65, 3, 17-34.

Jones Donald Strategic Partners (2000). Taking the plunge 2000, sink or swim? Small business attitudes to electronic commerce. National Office for the Information Economy: Commonwealth of Australia.

Kaplan, S. and Sawhney, M. (2000) E-Hubs: The New B2B Marketplace. Harvard Business Review, May/June, 97-103.

Kleindl, B. (2000). Competitive Dynamics and New Business Models for SMEs in the Virtual Marketplace. Journal of Development Entrepreneurship, Vol. 5, 1, 73-86.

Korchak, R. and R. Rodman, eBusiness adoption among US small manufacturers and the role of manufacturing extension. Economic Development Review, 2001. Vol. 17, 3, 20-25.

Lee, F., Vogel, D. and Limayem, M. (2003). Virtual Community Informatics: A Review and Research Agenda. JITTA: Journal of Information Theory and Application, Vol. 5, 1, 4763.

Lucking-Reiley, D., and Spulber, D. F. (2000). Business-to-Business electronic commerce. Journal of Economic Perspectives, Vol. 15, 1, 55-68.

Levy, M. and Powell, P. (2003). Exploring SME Internet Adoption: Towards a Contingent Model. Electronic Markets, Vol. 13,2, 173-181.

Lueg, C. (2003), Knowledge Sharing in Online Communities and its Relevance to Knowledge Management in the e-Business Era, Int. J. Electronic Business, Vol. 1, 2, 140-151.

McAdam, R., The implementation of reengineering in SMEs: A grounded study. International Small Business Journal, 2000. Vol.18, 4, 29-45.

Mirani, R., and Lederer, A. L. (1998). An instrument for assessing the organizational benefits of IS Projects. Decision Sciences, Vol. 29, 4, 803-838,

OECD, (1998) A Borderless World - Realising the Potential of Global Electronic Commerce, Ottawa, Canada 7-9 October, Organisation for Economic Co-operation and Development.

OECD, (2000). Enhancing the competitiveness of SMEs in the global economy: strategies and policies. Proceedings of the Conference for Ministers responsible for SMEs andIndustry Ministers. Bologna, Italy.

Pacific Access (2001) Yellow Pages Business Index SME Survey of Computer technology and E-Commerce in Australian Small and Medium Businesses, July. [URL: www.corporate.pacificaccess.com.au]

Poon, S. and Swatman, P.M.C. (1997) Internet-based Small Business Communication: Seven Australian Cases, Electronic Markets, Vol. 7, 2, 15-22.

Said, A.J. (2000). Helping small firms trade effectively with the Internet. International Trade Forum, 2000. 3, 16-19.

Small Business Index (1998). Small Business Index: a survey of e-commerce in Australian small andmedium businesses. Melbourne: Yellow Pages

Standing, C. The Characteristics of Successful e-Marketplaces. in Pacific Asia Conference on Information Systems. 2001. Seoul, Korea.

Standing, C. Vasudavan, V. (1999). Internet Marketing Strategies used by Travel Agencies in Australia. Journal of Vacation Marketing, Vol. 6(1), pp. 21-32,

Swatman, P. (2000). Internet for SMEs: A new skill road? International Trade Forum, 2000(3): 22-24.

Tetteh, E. and Burn, J. M. (2001). Global Strategies for SMe-Business: applying the S-M-AL-L framework. Journal of Logistics and Information Management, Vol 14, No 1 and 2, pp 171-180.

UNCTAD (2002) E-Commerce and Development Report, available at http://r0.unctad.org/ecommerce/ecommerce_en/edr02_en.htm. 
Williams, R. L. and Cothrel, W. J. (2000). For-Smart Ways to Run Online Communities. Sloan Management Review, 41, 4, 81-91. 